\title{
The influence caused by storage and photocatalyst layer of all plastic photo- rechargeable battery performance
}

\section{オールプラスチック光蓄電池性能の蓄電層·光触媒層依存性}

\author{
Takahiro KUBOTA and Sadao UEGUSA \\ Department of Electrical Engineering. Tokai University, 1117 Kitakaname, \\ Hiratsuka, Kanagawa, 259-1292 JAPAN \\ TEL:81-0463-58-1211 (EXT. 4162) \\ ( Received 15, November 1999 Accepted 13, March 2000)
}

The photo-rechargeable battery is element that photoelectric conversion and charge are possible by itself.

In this paper, construction of photo-catatytic rechargeble battery was studied, using organic materials.

By changing the polymerization quantity of the photocatalyst layer, an optimum point of generating eflicency was found.

Keywords: all plastic device, photo-rechargeable battery, organic pigment

\section{INTRODUCTION}

近年、石油やウランなど化石燃料の枯渇と公害問題が深刻 化している。そこで、クリーンなエネルギーとして太陽エネ ルギーが注目されている。太陽光を利用したデバイスは、太 陽電池などを中心に研究が行わ㣗てる。また、電子機器の 発展に伴い、小型大容量の蓄電池が必要とされている。

光蓄電池のアイデアは1980年代トリピッツ氏らにより電気 変換と蓄電が一つの素子内で連続したブロセスとして現実可 能として発表されたものである。 ${ }^{2}$ 日本では、鹿児島大学野 見山氏により、光触媒として $\mathrm{Ti}_{2}$ やPTaなど主に無機物質を 用い多面的に検討されている。 ${ }^{3}$ 本研究では、光触媒として 紫外域に光吸収分布の中心を有する傾向を示す無機物質の代 わりに、可視光域にも分布をもつ有機色素を用いた。また蓄 電材料としてポリパラフェニレン(PPP)を使用した。したが って、両者からなるテバイスとして全てを有機物質で構成さ せたという意味で、本蓄電池は世界初の試みである。これに より、有機物質は哭機物質に比べ機械的に柔軟性のある素子 作製が可能であり、このことも大きな利点として挙げられる。 本稿では、このオールブラスチック光蓄電池で蓄電層の重合 量を固定し、光促媒層の重合量を変化させることで、発電効 率がどのような特性を示すか詳細に検討した。

\section{BASIC PHYSICAL PROPERTY OF PHOTO-RECHARGEABLE BATTERY}

本蓄電池を構成している物質において、まず光触媒として 用いたオキソノール色素nk-3994 とnk-3995の各々と、その吸 光分布の合成図をFig. 1に示す。実線が2種類の色素の吸光分 布を合成したものであり、点線は各色素の岋光分布を示す。 一般に㷂機物質と比較し、有機物質は多様な吸光分布を示す 傾向にあり、このような工夫により紫外域から可視光域に至

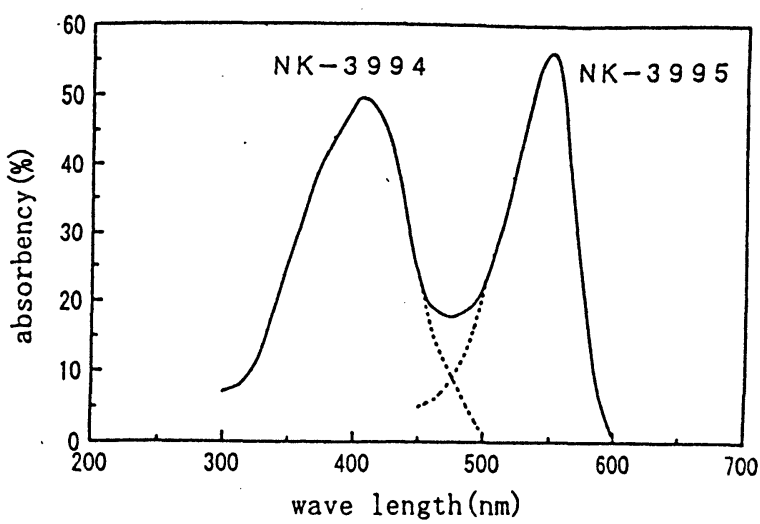

FIG. 1. The photo absorbed distribution of okisonor pigments. ${ }^{4}$

る光吸収分布を持たせることができ、より効率が高い光需変 換を行える可能性がある。

次に、本蓄電池を構成している物質の真空レベルからの工 ネルギーレベルとエネルギーギャッブをTablelに示す。そし てこれを図示したのがFig. 2である。同図から明らかなよう に光触媒首に光照射することにより、光触媒である色素の価 電子带から伝導带へ電子が励起される。そして、同時に洒要 子带にホールが生じる。このホールに笔解溶波から雷子が受 け渡され、ホールを埋めることになる。励起された電子は光 触媒層からエネルギーレベルの低い堷電首へと移動し、蓄電 される。本㸴究では本オールブラスチック光蓄電池を用い、 蓄電層の重合量を固定し、光触媒層の重合是を変化させた。 この目的として、光触媒首を增加させれば、その分だけ膜に 取り込まれる色素の量も增加する。これより光励起筑子数も 多くなり、発電效率は增加すると考えられる。一方、その而 
TABLE 1. Band gap and energy level from vacuum.

\begin{tabular}{|c|c|c|}
\hline $\begin{array}{c}\text { kind of } \\
\text { material }\end{array}$ & $\begin{array}{c}\text { energy level } \\
\text { from vacuum }(\mathrm{eV})\end{array}$ & band gap (eV) \\
\hline Al electrode & -6.18 & \\
\hline $\begin{array}{l}\text { okisonol } \\
\text { pigment nk-3994 }\end{array}$ & -4.03 & 2.44 \\
\hline $\begin{array}{l}\text { okisonol } \\
\text { pigment nk-3995 }\end{array}$ & -4.03 & 2.04 \\
\hline PPP & -4.73 & 3.20 \\
\hline Nesa-glass & -4.90 & \\
\hline
\end{tabular}

\section{$\mathrm{R}$}

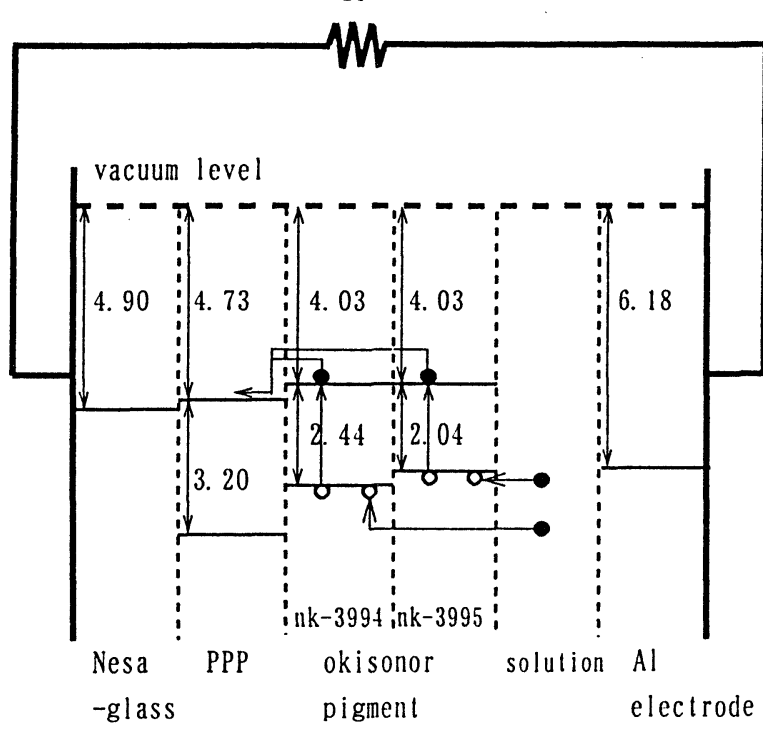

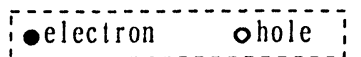

Unit of numbers are ev.
FIG. 2. The energy level of each materials.

合量を增加させ、膜厚が增加すると電子の寿命洔問内に蓄電 首に到達できない電子量も增加するはずである。そこで光触 媒首の重合量に発電效沵の最適点が生じると想定し、以下の 実験を行った。

\section{EXPERIMENTAL}

本研究では、蓄電層と光触媒層の 2 層棈造となっている。 まず蓄電層膜の電解重合は、50ccのビーカーにTable2の媒質 を入れ、十分拍拌した。その後真空引きを行い、これを電解 溶液とした。主電極はネサガラスであり、対向電極はアルミ 板とし、両電極を $2 \mathrm{~cm}$ の間隔に設置し、溶液中に片側電極あ たり $4 \mathrm{~cm}^{2}$ 捚入した。これにクーロンメーター、電源、電流計、 電圧計：ダイヤル可変抵抗器をFig. 3に示すように配線した。 そしてスイッチを(1)侧にセットし、雨電極間に電圧20Vを印 加し、2C重合させた。次に光触媒層を作製するために、他の ビーカーにTable2の物質の他にオキソノール色素nk-3994、 nk-3995を10mgづつ加え、これも十分擤捧したのちに真空引 きを行い、光触媒層を重合するための電解溶液とした。そし てすでに蓄電首を製膜したセルをこのビーカーに挿入し、さ
TABLE 2. The materials of solution.

\begin{tabular}{|c|c|}
\hline kind of material & quanlity \\
\hline nitorobenzene & $35.0(\mathrm{cc})$ \\
\hline benzene & $3.28(\mathrm{cc})$ \\
\hline copper (II) chloride & $46.9(\mathrm{mg})$ \\
\hline $\begin{array}{c}\text { lithium } \\
\text { hexafluoroarsenate }\end{array}$ & $68.3(\mathrm{mg})$ \\
\hline
\end{tabular}

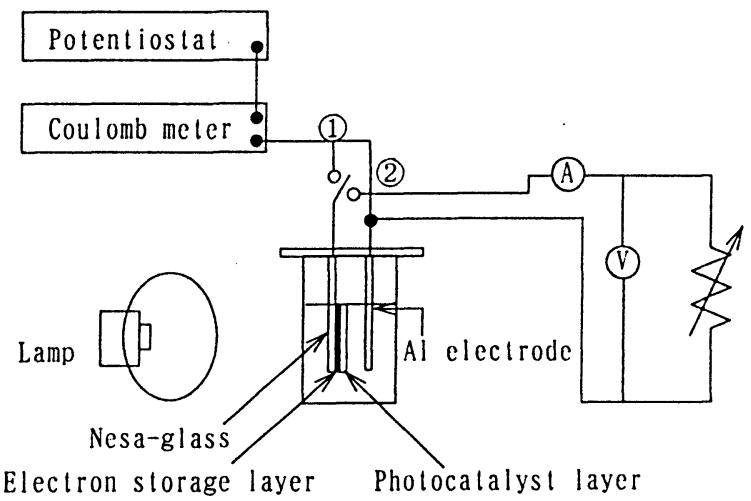

FIG. 3. Experimental apparatus.

らに所定の量を重合させ、光触媒首とした。

次に测定方法を示す。Figure3において、スイッチを(2)侧 にセットし、照射光をレフレックスランブで照射し、試料面 における光強度を $30 \mathrm{~mW} / \mathrm{cm}^{2}$ に設定した。ダイヤル可変抵抗を

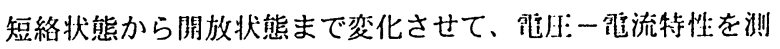
定し、そのデータから発電効㳯を求めた。

\section{N. RESULTS AND DISCCUTION}

Figure4に、光触媒層の重合量が0.3Cの場合の雪压一雷流 特性を示した。同図から、本条件における最大出力動作霆流 および最大出力動作電压は0.054mA、509mVであった。また、 発電効率は0.023\%となった。

Figure5は闹一条件における具衡抵抗一舵力特性を示す。 同グラフにおける電力のピーク点を与える員街抵抗が光湆雪 池のマッチング抵抗を示す。これより、同条件におけるマッ チング抵抗は $9 \mathrm{k} \Omega$ であった。また、このときの最大山出電力 が27. 5 ル サである。

次に、光触媒層の重合量の各条件におけるマッチング抵抗

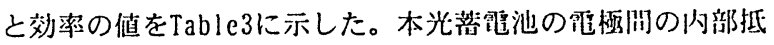
抗はFig. 6に示すように、萻電層、光蜰媒層、溶液の 3 部分 の直列接続として表すことができる。立 2 者の抵抗率は、約 $0.01(\Omega / \mathrm{cm})$ であるので、"溶液の抵抗が最も高いと考えられ る。それは、0.1C〜0.5Cの篹盲の重合膜に対するマッチング 抵抗の值の変化が小さいことにも現れている。また、重合星 1. 0 Cの光促媒層の場合膜厚が最も厚く、後述のように我解漁 液側の光励起電子が蓄電首まで到達しにくいため、雪流が極 端に減少する倾向を示す。このため、結果的に内部抵抗が上 昇したと考えられる。Figure 7に光触媒層の重合量一效率特性 を示す。同図から明らかなように、光㑁媒首の重合是が $0.3 C$ 


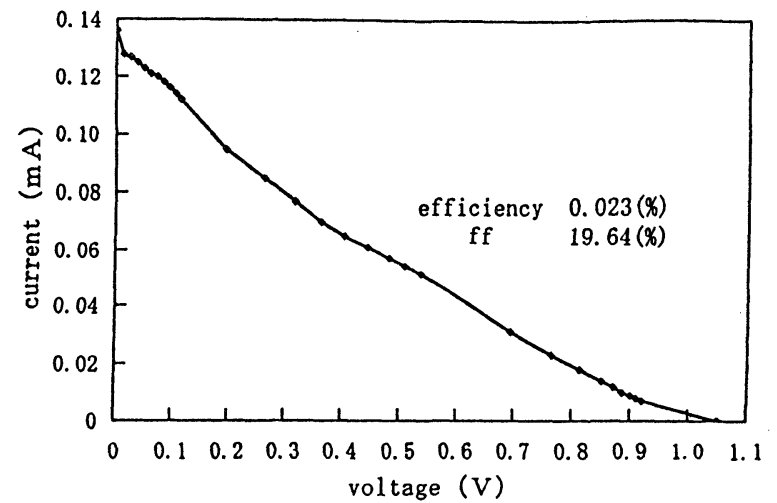

FIG. 4. Characteristic of voltage and current.

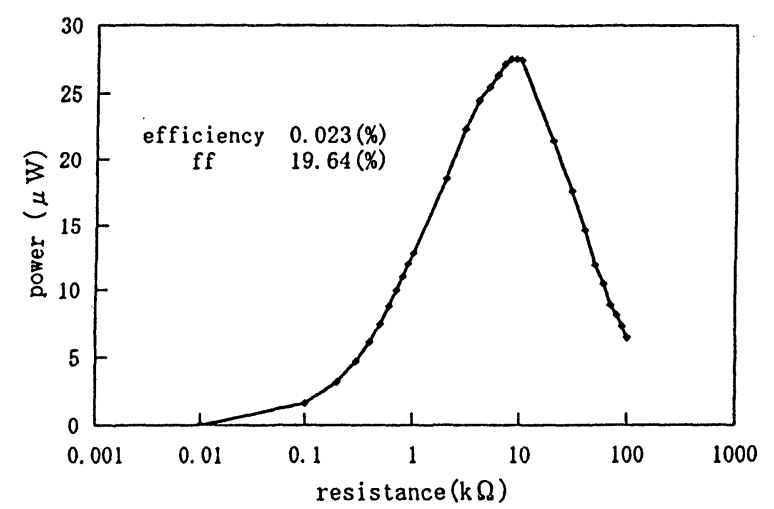

FIG. 5. Characteristic of resistance and power.

TABLE 3. Experimental Result.

\begin{tabular}{|c|c|c|}
\hline $\begin{array}{l}\text { polymerizalion } \\
\text { quanlily of } \\
\text { pholocalalys l layer (C) }\end{array}$ & $\begin{array}{l}\text { malching } \\
\text { resislance }(\mathrm{k} \Omega)\end{array}$ & clficiency $(\%)$ \\
\hline 0.1 & 9 & 0.00094 \\
\hline 0.2 & 8 & 0.01100 \\
\hline 0.3 & 9 & 0.02338 \\
\hline 0.35 & 8 & 0.01238 \\
\hline 0.4 & 7 & 0.01013 \\
\hline 0.5 & 9 & 0.00688 \\
\hline 1.0 & 20 & 0.00542 \\
\hline
\end{tabular}

時でピークを示している。ここで光励起電子の挙動をFig. 8 を用いて考察する。同図の光蚛媒層が光照射されることによ り、IIに記述した過程で墇電が行われる。

このブロセスにおいて、光促媒首の電解溶液侧と蓄電層侧 では電子の移動に違いが生ずる。すなわち、電解溶液側では ホールを埋めるための電解溶波から供給される電子は、溶波 と接しているために容易に移動することが山来る。しかし、 励起された電子は蓄電層に到達するのに、光朏媒層の厚さに 相当する距别俳を移動しなくてはならないので、その途中で

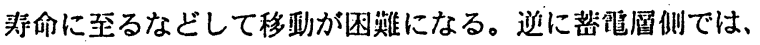

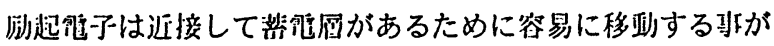
できるが、逆に溶波から供給される熋子でホールが䧳まるた めには、それて反対に、光螆媒層の厚さがあるために電子移 (a) (b)

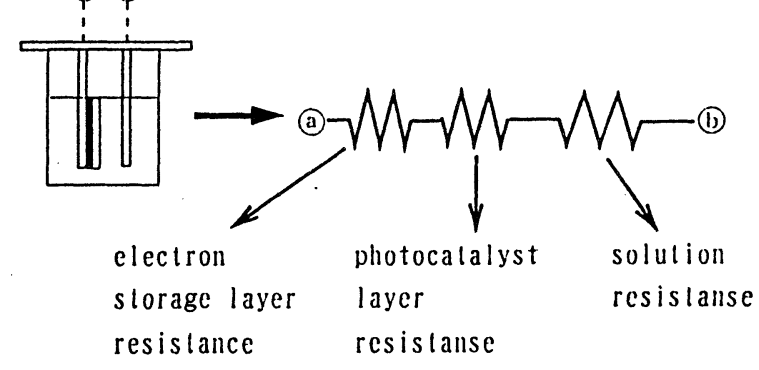

FIG. 6. Resistance betwecn two cleclrode.

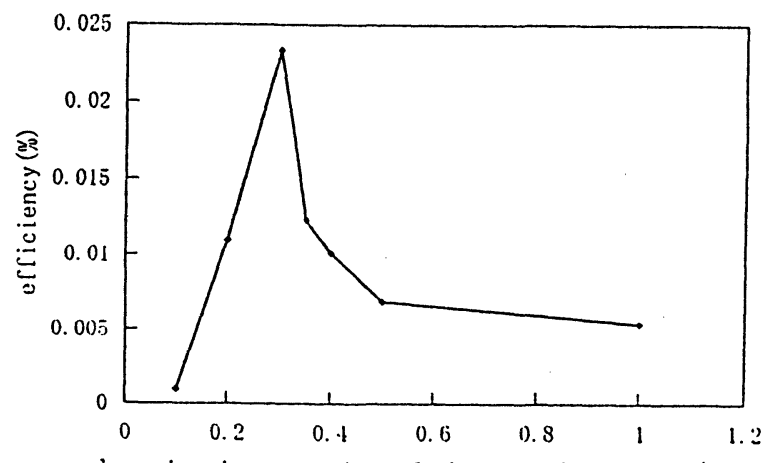

polymerization quantity of photocalalyst layer(C)

FIG. 7. Characteristic of polymerization quantity of photocatalyst layer and efficiency

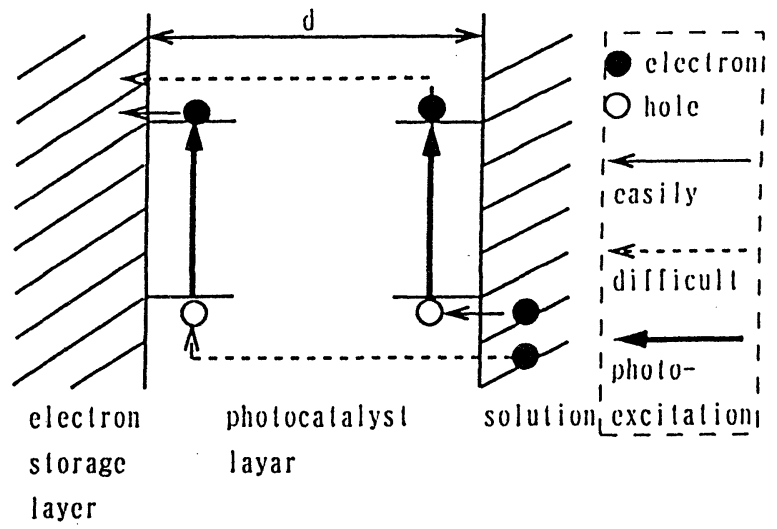

FIG. 8. The pholoelectronic movement.

\section{動が困難になると考えられる。}

このため、光㑁媒層の電解溶液侧と菩電首侧では励起雪子 密度に違いが生じると考えられる。すなわち、萻電首侧と電 解溶液側それぞれの光励起により生じる一対の電子とホール の再結合を考えた場合、電解溶液側では溶波からの電子の移 動が容易に行われ、ホールが埋まるので、再結合しにくいと 考えられる。よって、励起電子の寿命時間も長くなると考え られる。それに比べ、萻雨層侧では溶波から補充される炛子 の移勁が難しく、光倣起により生じたホールが包子で圳まり

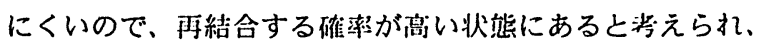
寿命時間は短くなるものと考えられる。よって、Fig. 9に示 


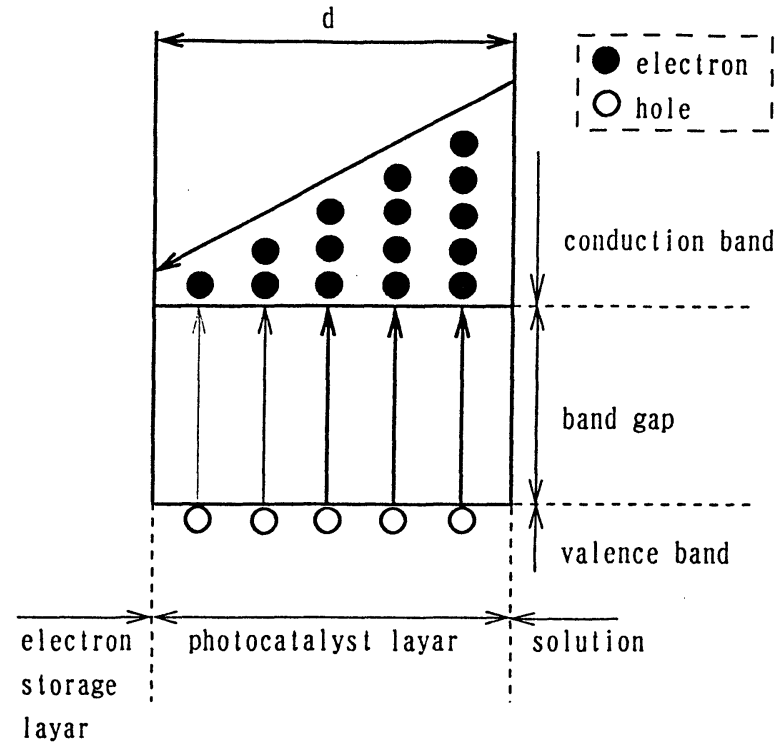

FlG. 9. The gradient of electrons.

すように電解溶波側と蓄電層側全体を考えると、伝導帯にお ける両者の電子に密度勾配が生じる。これにより蓄電層方向 へ電子が拡散により移動すると考えられる。

ここで、電荷qを持ったキャリアが単位体積 $\left(\mathrm{cm}^{3}\right)$ あたりn 個存在するときに、導伝率を $\sigma(\mathrm{S} / \mathrm{cm})$ とすると、キャリアの 移動度 $\mu\left[\mathrm{cm}^{2} /(\mathrm{V} \cdot \mathrm{s})\right]$ は、

$$
\mu=\sigma / \mathrm{n} \mathrm{q}
$$

で表わすことができる。

また、光照射により朸起電子は長時間伝導率に存在できず、 ある時間が経過すると佂電子带のホールと再結合したり、禁 止帯中のトラッブ淮位に落ちる。その平均時間を寿命時間 (s)とし、光未照射時の両電極物質固有のポテンシャル差を 電極間隔で割った平均電界 $\mathrm{E}(\mathrm{V})$ における電子移動距離を $\mathrm{L}$ (cm) とすると

$$
\mathrm{L}=\mu \tau \mathrm{E}
$$

となる。これに(1)を代入して

$$
\mathrm{L}=\sigma \tau \mathrm{E} / \mathrm{n} \mathrm{q}
$$

となる。

ここで光触媒層の厚さをdとして、3つの条件(1) d $<\mathrm{L}$ 、(2) $\mathrm{d}=\mathrm{L} 、(3) \mathrm{d}>\mathrm{L}$ の場合について考察する。

1) (1)の場合は励起された電子がすべて蓄電首まで到達す ることができるので、到達電子数は林大きくなるにつ れて、增えると考えられる。

2) (2)では(1)においてdを徐々に大きくした場合の到達電 子数がピークとなった点であり、最も電解溶液側で光励 起した電子が蓄電層まで到達することができる。

3) (3)では光励起が最も多い電解溶液側の電子が時間 $\tau$ 内 に蓄電首まで到達できずに、仙電子带のホールと再結合
するため、到達電子数は減少すると考えられる。

よって、(2)の場合が最も蓄電効率が良く、光励起電子を蓄 電層に到達させることができると考えられる。

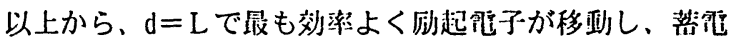
首に到達すると見ら㧈、このため、本実騟条俳では光蚛媒首 の重合量0.3Cでピーク点が表社たと考えられる。

\section{CONCLUSION}

1）本オールブラスチック光萻電池において、以下のよう な電子の詳細な動きが確認された。

(1) 光蓄電池の光㑁媒層に光照射することにより、光㑁 媒である色素の仙電子带から伝道怵へ电子が河起され る。そして、同時に仙電子带にホールが生じる。この ホールに電解溶波から電子が受け渡され、ホールを埋 めることになる。励起さ㧈た霆了は光促桇厝からエネ ルギーレベルの低い蓄雪首へと移動儿、帮䍡される。

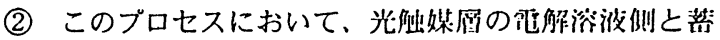
電層側では電子の移動に避いが生じ、伝導带の闬子に

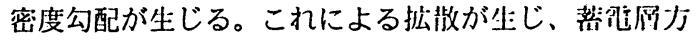
向へ電子が移動すると考えられる。

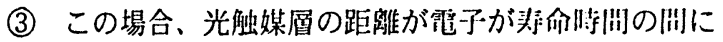

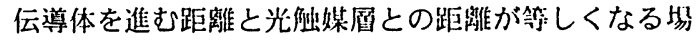
合に、最も効率よく電子が移動し、蓓篟原に到達する と見られ、本実験条件では光㑁媒層の亚合园0.3Cでピ 一ク点が表れたと考えられる。

2）電子が㭋命特間の間に伝導体を進む距陫と光蚛媒居と の距踓が等しくなる場合以上の膜厚にしても、効染は上 がらないことが碓認された。

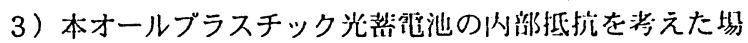
合、膜の内部抵抗よりも溶波抵抗が装子全休の内部抵抗 に、より大きな影響を与えることが碓諗された。

\section{REFERENCES}

'D. Kaneko, The influence caused by parlicle diameter of $\mathrm{Ti}_{2}$ for photo-rechargeable battery performance. Graduation thesis, (1998) p2. 3

${ }^{2}$ H. Tributsch, Sorid state logics, (1983)

${ }^{3}$ T. Nomiyama. The development of the photorechargeable batlery electrode using the polypyrrole of electroconductive polymer. The Japan society of applied physics. (1996)

1 Y. Shimizu, Trial manufaclure and properly of all plastic photo-rechargeable battery. Electric academic meeting national convention, (1997) p. 1

${ }^{5} \mathrm{~K}$. Yosino. Base and application of the electroconduclive polymer. (1987) p158 p162 